\title{
東京都心区部における下水処理水の広域活用に関する調査研究 A STUDY ON WIDE AREA UTILIZATION OF THE TREATED WATER FROM SEWAGE DISPOSAL PLANT IN THE INNER CITY DISTRICT OF TOKYO
}

増田幸宏*

Yukihiro MASUDA

\begin{abstract}
We have large quantity of treated water from sewage disposal plant. It is valuable water source in the city. I pointed it out that we can utilize the treated water in the buildings, that already have facilities for wastewater reclamation and waterworks for miscellaneous use in the inner city district of Tokyo. I examined distribution and concentration of such kind of buildings. After the survey I found comparatively high concentration in the area around Tokyo station and there is a possibility that we can utilize the treated water from sewage disposal plant effectively in that area.
\end{abstract}

Keywords : Waterworks for miscellaneous use, Water for miscellaneous use, treated water from sewage disposal plant,

雑用水道, 雑用水, 下水処理水

\section{1. 研究目的. 研究概要}

都市において、下水処理水は都市内の需要地に近く、かつ量的 に安定した水源であると考えられる。下水処理水の活用は都市の水 に対する自立性、自律性を確立するための有勃な一方策である。東 京都の計画においても、今後下水処理水を利用した広域循琹を拡大 し雑用水利用を促進するとある1)。

水資源としての下水処理水の有効な活用方法としては、既成市街 地の業務集糟地における雑用水*1としての利用が考えられる。しかし 下水処理水の広域循環は通常新規の広域の再開発等で導入される ため、既成市街地においては、雑用水道の方式として個別・地区循 環方式の施設が集積しつつある。図 1 に示すのは雑用水利用施設数 の推移である2。後述の通り、個別・地区循環方式の雑用水利用は 建物毎にプラントを設置する形式のため普及が容易であるが、雑用 水需要を賄う雑用水を確保できない場合がある。

個別・地区循㻴方式の建物は雑用系統と上水系統の二系統配管 を既に有するため、下水処理水の供給を受けてすぐに雑用水として利 用することが可能である。そのため、個別・地区循環方式の建物が ある程度集積し、一定規模以上のまとまった雑用水需要がある地域に 対しては、雑用水需要を賄うために下水処理水を供給することが考え られる。
そこで本報においては、個別・地区循環方式の建物による雑用水 需要を下水処理水の供給対象として捉え、下水処理水の広域活用に 資する資料とするため、東京都区部における個別・地区循環方式で 雑用水利用を行う施設を対象とし、その集積状況と雑用水需要量につ いて調查を行う。

\section{2. 雑用水需要と下水処理水の現況}

\section{1 下水処理水の現況}

再生水としては主として下水高度処理水*2が利用されている。平成 12 年度で区部における処理水全体 (約 476 万 $\mathrm{m}^{3} / \mathrm{day}$ ) の約 $10.3 \%$ 程度 $\left(49\right.$ 万 $\left.\mathrm{m}^{3} / \mathrm{day}\right)$ が高度処理されている3)。将来的には、総処 理量の $100 \%$ 目標としながら、平成 27 年に向けて総処理水量の 60 \%を目標に高度処理の導入をはかるとしている1)。広域循渨による雑 用水利用、清流復活事業用の㻴境用水等に用いられている処理水 は平成 12 年度で処理水全体の約 $1.5 \%$ 程度（約 6 万 $\mathrm{m}^{3} / \mathrm{day}$ )、下水 処理場内での利用も含めると約 $9 \%$ 程度である3)。表 1 に示すのは、 東京都区部の下水処理場における高級処理水と高度処理水の放流量 である3)。

\section{2 東京都区部における雑用水需要の現況}

表 2 に示すのは、東京都区部の各区における個別循睘、地区循

* 早稲田大学大学院理工学研究科 博士後期課程 $\cdot$ 工修 Doctoral Course, Graduate School, Waseda Univ., M. Eng. 
環、広域循罡の各方式における雑用水需要（利用計画水量）の現 況である。個別・地区循璒利用施設では、雑用水需要量で比較す ると值の大きなものから千代田区、港区、品川区、新宿区、中央区 の順であり、雑用水需要密度で比較すると千代田区、港区、中央 区、政谷区、文京区の順となっている。

\section{3 東京都区部における下水放流量と雑用水需要の比較}

表 1 ，表 2 より、東京都区部における下水放流量と雑用水需要量 の比較を行ったものが図2である。下水放流量約 440 万（ $\left.\mathrm{m}^{3} / \mathrm{day}\right)$ に 対して、個別循環、地区循票方式における雑用水需要量（利用計

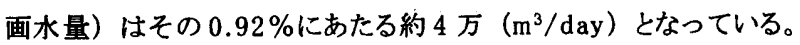

\section{3.雑用水道方式の変更に関する検癿}

\section{1 雓用水道利用の方式*3}

現在、建築物に迸入される雑用水道には 3 通りの方式がある。 個々の建物で循環利用水造成プラントを設置する個別循環方式、地 区レベルで循環利用水造成プラントを設置し、複数の建物に循環利

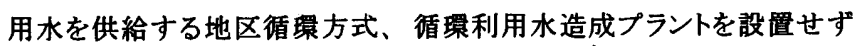
下水処理場から再生水の供給を受ける広域循㫤方式の3種類である *4。現在東京都の「雑用水利用に保る指導指針」においては、延 へ休面積 3 万 $\mathrm{m}^{2}$ 以上、あるいは雑用水量（計画可能水量） $100\left(\mathrm{~m}^{3} /\right.$ day）以上の建築物の建築主及び雑用水利用管理者に対して雑用水 利用実施の指導を行っている。雑用水道の方式の選択に関しては、 個別・地区循琹方式に加えて、下水処理場からの再生水の供給が 可能な区域においては広域循懪方式も検討することとなっている。広 域循環方式の実現にあたっては、下水処理場から需要地までの再生 水供給管の敷設に要するコストを賄う需要が必要等の制約があり、新 規の広域の再開発等限られた地域でしか実現していない。

\section{2 㨁環利用水造成プラントを設置する場合の問題点}

広域循晋方式と比較して循環利用水造成プラントを設置する場合の 主な特徵をまとめると、長所としては普及・促進が容易であること、下 水の排出量が堿少することが举げられ、短所としては個別の建物に
おいてプラントの設置、維持管理、污泥処理等が必要でコストがかか ること、各建物毎にプラントの構成と規模を設計することになるが建物 によっては雑用水の需給バランスが取りにくいこと、また設計時点での 計画通りの需要量、供給量とならない場合があることが挙げられる。

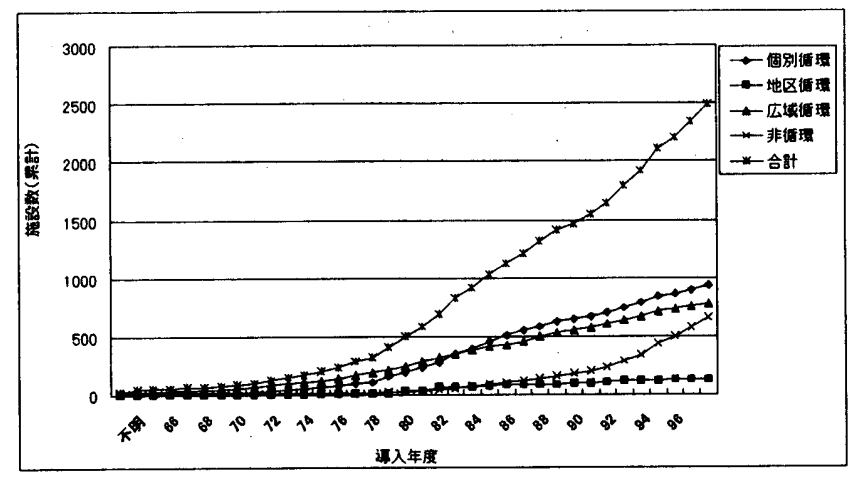

图 1 运入年度別雑用水利用施設数

表 1 下水処理場の放流量

\begin{tabular}{|c|c|c|c|}
\hline 超理埥名 & 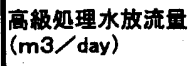 & $\begin{array}{l}\text { 高度処理水放流量 } \\
\text { (m3３／day） }\end{array}$ & $\begin{array}{l}\text { 放流量合尌 (m3/ } \\
\text { day) }\end{array}$ \\
\hline 芝浦 & 661,622 & 0 & 661,622 \\
\hline 三河息·果属风 & 249,703 & 138,262 & 387,965 \\
\hline \multicolumn{4}{|l|}{ 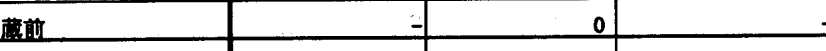 } \\
\hline 中III & 168,929 & 0 & 168,929 \\
\hline 少査 & 244,636 & 0 & 244,636 \\
\hline 直明 & & 7,252 & 7,252 \\
\hline 小者 & 159,152 & 0 & 159,152 \\
\hline 葛酉 & 313,443 & 0 & 313,443 \\
\hline 落合 & 13,813 & 261,531 & 275,344 \\
\hline 中埋 & 27,139 & 0 & 27,139 \\
\hline 斩河崖 & 551,186 & 0 & 551,186 \\
\hline 杪町 & 426,194 & 0 & 426,194 \\
\hline 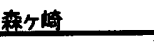 & $1,168,568$ & 0 & $1,168,568$ \\
\hline 8 & $3,984,385$ & 407,045 & $4,391,429$ \\
\hline
\end{tabular}

（注）東京都下水道事集年耛（平成 12 年度）をもとに作成

表 2 東京都区部における個別循環、地区循㻴、広域循環の各方式における雑用水需要の現況

\begin{tabular}{|c|c|c|c|c|c|c|c|}
\hline 区名 & 個別循罯 & 地区看理 & 庄城循環 & 各区面樌 & 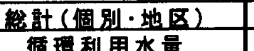 & 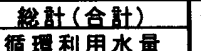 & 雉用水霣要密度（個別－地区） \\
\hline & & 循環利用水量 & & & & & \\
\hline & $\left(m^{3} /\right.$ day $)$ & $\left(m^{3} /\right.$ day $)$ & $\left(m^{3} /\right.$ day $)$ & $\left(\mathrm{Km}^{2}\right)$ & $\left(m^{3} /\right.$ day $)$ & $\left(m^{3} / d a x\right)$ & $\left(m^{3} / m 2 \cdot\right.$ day $)$ \\
\hline 毛代田区 & 5145 & 4406 & & 11.64 & 9551 & 9551 & 0.000821 \\
\hline 港区 & 6906 & 1614 & 2064 & 20.34 & 8520 & 10584 & 0.000419 \\
\hline 中央区 & 2423 & 591 & -1 & 10.15 & 3014 & 3014 & 0.000297 \\
\hline 漇公区 & 2296 & 416 & - & 15.11 & 2712 & 2712 & 0.000179 \\
\hline 文京区 & 1642 & 382 & -1 & 11.31 & 2024 & 2024 & 0.000179 \\
\hline 新侣区 & 791 & 2284 & 6601 & 18.23 & 3075 & 9676 & 0.000169 \\
\hline 唱川区 & 1798 & 1623 & 69 & 22.69 & 3421 & 3490 & 0.000151 \\
\hline 豊量区 & 516 & 1240 & -1 & 13.01 & 1756 & 1756 & 0.000135 \\
\hline 具愚区 & 176 & 1332 & - & 14.7 & 1508 & 1508 & 0.000103 \\
\hline 大田区 & 2544 & - & - & 59.46 & 2544 & 2544 & 0.000043 \\
\hline 台車区 & 352 & - & 7 & 10.08 & 352 & 352 & 0.000035 \\
\hline 世田公区 & 118 & 373 & $\exists$ & 58.08 & 491 & 491 & 0.000008 \\
\hline 北区 & 155 & -1 & $\exists$ & 20.59 & 155 & 155 & 0.000008 \\
\hline 中野区 & -1 & 113 & 555 & 15.59 & 113 & 668 & 0.000007 \\
\hline 量田区 & 93 & - & -1 & 13.75 & 93 & 93 & 0.000007 \\
\hline 足立区 & 358 & - & - & 53.2 & 358 & 358 & 0.000007 \\
\hline 江東区 & 263 & - & 3862 & 39.44 & 263 & 4125 & 0.000007 \\
\hline 科崖区 & 310 & - & -1 & 48.16 & 310 & 310 & 0.000006 \\
\hline 杉並区 & 101 & - & - & 34.02 & 101 & 101 & 0.000003 \\
\hline 板椱区 & 60 & - & - & 32.17 & 60 & 60 & 0.000002 \\
\hline 荒川区 & -1 & -1 & - & 10.2 & 0 & of & 0.000000 \\
\hline 䖲篮区 & -1 & - & -1 & 34.84 & of & of & 0.000000 \\
\hline 江声川区 & - & -1 & -1 & 49.86 & 0) & 요 & 0.000000 \\
\hline 䲞 & 26047 & 14374 & 13151 & $616 ; 62$ & 40421 & 53572 & 0.000066 \\
\hline
\end{tabular}


図1に示すように雑用水利用施設の設置数が増加している一方で、 維持管理の問題等から利用を停止した施設も見られ、個別循摆方式 では維持管理費の負担が大きいこと、水量が不足していること、原 水の水量・水質が不安定であること等が課題として報告されている7)。

\section{3 再生水を供給する場合の有効性}

個別・地区循環方式で雑用水利用を行う建物に再生水の供給が 可能になった場合、以下の4点の有効性が挙げられる。

(1)一定の水質の再生水を需要に忘じて安定して供粭可能である。

(2)雑用水需要に対して排水量が少ない建物でも雑用水利用が可 能となる。

(3)雑用水需要が少なく、利用コストの点からプラントを設置しての 雑用水利用が困難である建物でも雑用水利用が可能となる。

(4)必要な水量が常時確保できるため、全雑用水系用途へ雑用水 利用を拡大することが可能である。

(4)に関しては、再生水を供給することにより需要に応じた雑用水利 用が可能になる。現在は「建築物における衛生的環境の確保に関 する法律」（以後、ビル管理法）*5により散水や空調用水源に再生 水を使用することが難しいが、水質管理に関しての技術的な対応に より将来的には利用可能であると考えると、表 3 を用いれば、雑用水 系統として最終的に最大で水消費量の $58 \%$ 程度まで雑用水の需要 が增加する可能性が考えられる12）13)。

\section{4 雑用水道方式の变更に関する技術的検时}

個別・地区循睯方式で雑用水利用を行う建物に再生水の供給を 行う場合、雑用水道方式の変更に要する技術的な検討を行う必要が ある。個別循環方式で循利用水を利用している建物が雑用水利用 を全量再生水に変更するとした場合、循㻴利用水造成プラントの一 部を工事することで再生水の供給を受けることが可能となる。その際 図 3 に示すようなシステム変更が考えられる。

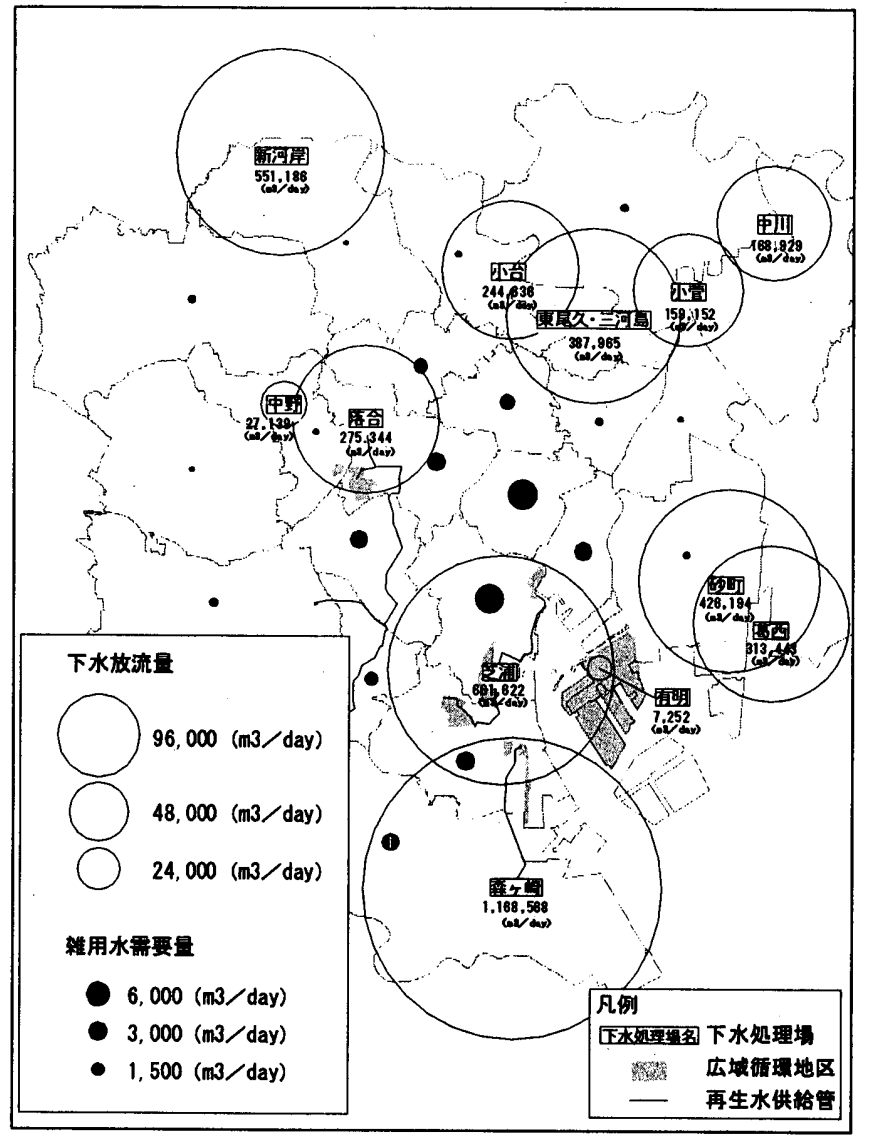

図 2 東京都区部における下水放流量と倜別彺環、地区循環 方式における雑用水需要量の比較

表 3 オフィスビルにおける用途别使用水量割合 ${ }^{21}$ （\%)

\begin{tabular}{|c|c|c|c|c|}
\hline \multicolumn{3}{|c|}{ 㒕用系用梌 $(58 \%)$} & \multicolumn{2}{|c|}{ 上水系用途 (42\%) } \\
\hline トイレ洗浄水 & 散水 & 空輖 & 手洗い.洗面 & 旗房 \\
\hline 30 & 3 & 25 & 15 & 27 \\
\hline
\end{tabular}

（注）文献12の用途別使用水量制合をもとに、雓用系用途と上水系用途の分類を加え 七表示

雑用水道システムの変更に要する工事：工事 1 排水貯留槽、再生処理施設の除去

工事 2 外部からの再生水供給管の雑用水貯留槽への接続

变更前 : 個別循環方式による雑用水利用

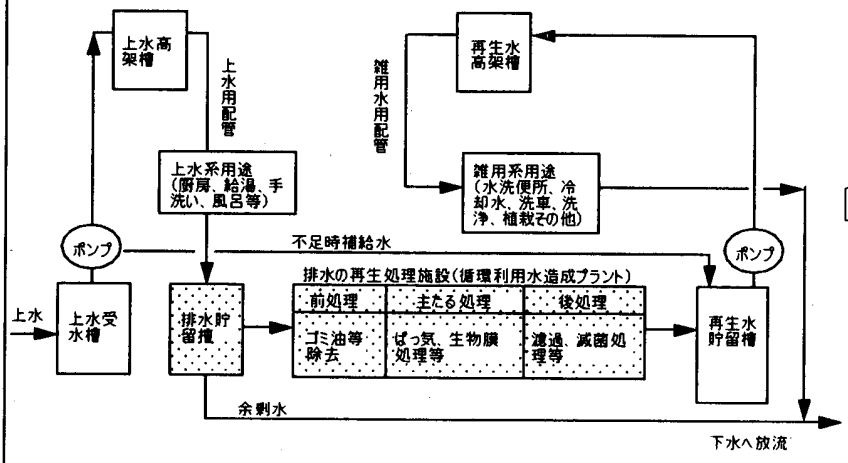

変更後 : 再生水の供給を受けての雑用水利用

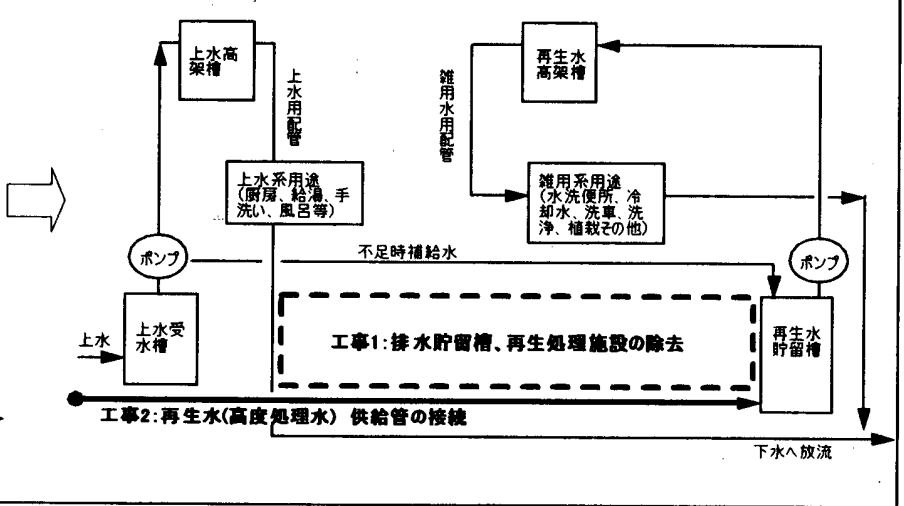

图 3 雓用水道システムの变更 


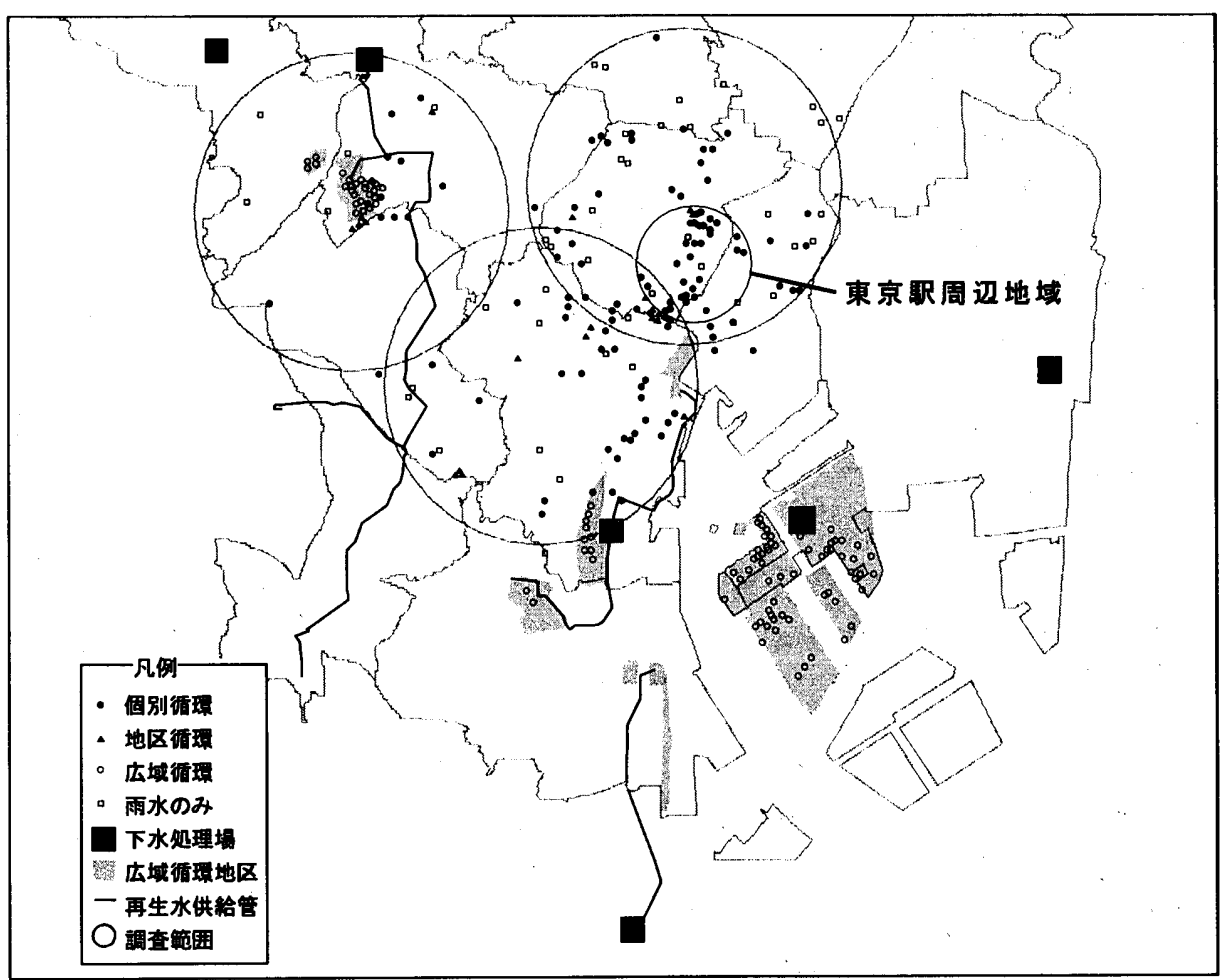

図 4 東京都心区部における雑用水利用施設の分布

\section{基本的には、}

・排水貯留槽、再生処理施設の除去

・外部からの再生水供給管の雑用水貯留槽一の接続

といら 2 段階の工事でシステムの変更が可能であり、個別・地区循 鏝方式で雑用水利用を行う建物は、再生水の供給先として現実的な 対象であると考えることができる。

\section{4. 東京都区部における再生水利用の検討}

\section{1 検的対象地区の抽出}

2.2 で述べた東京都区部の各区における個別循環、地区循環方 式における雑用水需要量 (利用計画水量) に関して、雑用水利用 を行う施設の集積状況と雑用水需要量のより詳細な把握を行うため、 以下の作業を行った。

循環利用水造成プラントを設置している既存の建物の集䅡の状況 を把握するためには、循環利用水造成プラント設置施設の分布が重 要になってくる。図 4 は、雨水のみを利用している施設も含めた雑用 水利用施設の分布を示すものである*6。分布図の作成にあたり、東 京の都区部の中でも多くの事務所ビルが存在する業務集積地である 新宿、大手町、六本木の 3 地域を対象とした。予備調査において、 当該地域の利用施設の分布は各々凡そ半径 $3 \mathrm{~km}$ の範囲となっている ため、その範囲で調查を行った結果を図 4 に示している。尚、下水 処理場と現在広域循㻴方式を導入している地区に隣接するほど、再 生水供給管敷設の点で再生水の供給が容易となるため、図 4 にそれ らをあわせて図示している。

図 4 より、東京駅周辺地域の雑用水利用施設は比較的多くの集稙 が見られるため、検討対象として取り上げさらに詳細な検討を行った。

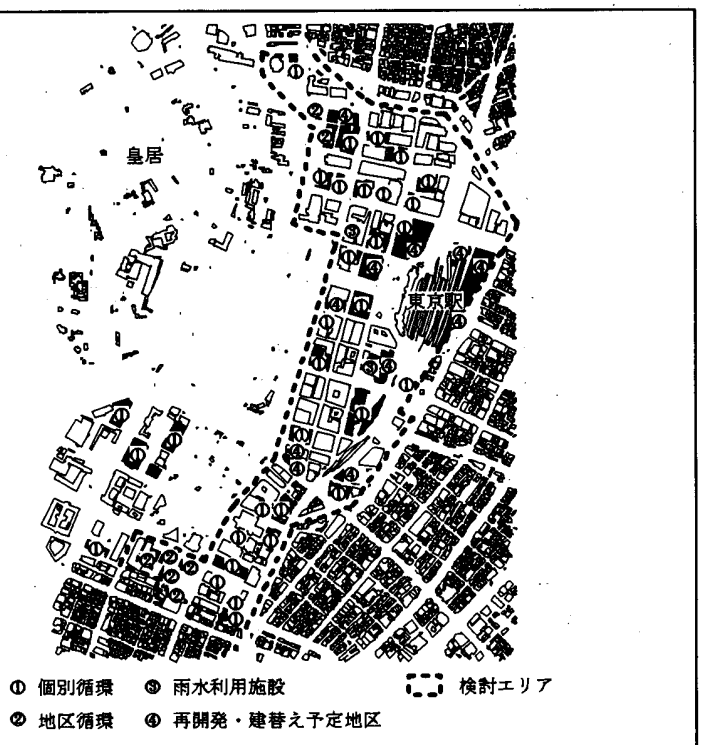

図 5 東京期周辺地区における倠用水利用施設

\section{2 東京駅周辺地域における検討}

（1）東京駅周辺地域を拡大したものを図 5 に示す。図 5 には、既 存の雑用水利用施設に加え、地域の動向として今後の再開発や建物 の更新に関して調查を行った結果も示している*?。その結果、雑用水 利用施設の集積の見られる図 5 に示すエリアを検討エリアとして設定 し、雑用水需要量の検討を行った。（以後検討エリアとする。）検討エ リアには延べ床面積 $500 \mathrm{~m}^{2}$ 以上の建物は約 120 棟あり*8、その内既 に 37 棟の建物で雑用水利用が行われている。検討エリア内の雑用 水利用施設の内訳は、個別循環方式 28 棟、地区循睘方式 2 件（建 
物計 7 棟)、雨水のみ利用の施設 2 棟である。これらの循環利用水 を利用する建物に関して、個別循環方式 28 棟の内 8 棟、地区循環 方式の 7 棟の内 6 棟の雑用水利用㥶態調查の結果を表 4 に示寸*9。 調查対象となっている 10 件中 8 件で雑用水の不足から雑用水系統一 の上水補給がされており、その 8 件の上水補給割合（上水補給量 $\div$ 雑用系統使用水量）の平均は $29.7 \%$ である。この結果より、検討エ リア内にお゙いては、再生水の供給により雑用水使用量は增加すると 推測される。尚、調查対象の 8 件の建物における雑用水使用量の 增加分は、上水補給量の合計である $480\left(\mathrm{~m}^{3} / \mathrm{day}\right)$ となると考えられ る。

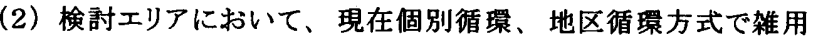
水利用を行っている 35 件の建物は、雑用水需要量（計画可能水量） $7,450\left(\mathrm{~m}^{3} /\right.$ day $)$ の規模である。今後の再開発（11 件、延へ床面 積合計 157 万 $\left.\mathrm{m}^{2}\right)$ において見込まれる雑用水需要量は、ビル管理 法に基づきトイレ洗浄水の用途を想定すると $3,594\left(\mathrm{~m}^{3} / \mathrm{day}\right)$ の規模 である*10。その結果、表 5 に示すように検討エリアにおける雑用水

\section{表 4 诸環利用水利用施設の実態調査結果}

\begin{tabular}{|c|c|c|c|c|c|c|}
\hline 連物 & $\underset{(\mathrm{m} 3 / \mathrm{dy})}{\text { 上水使用基 } \mathrm{P}}$ & 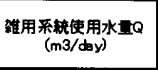 & 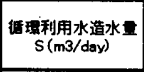 & 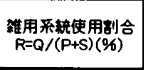 & 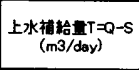 & $\begin{array}{c}\text { 上水補耠剧 } \\
\text { 合U=T/Q } \\
(\%)\end{array}$ \\
\hline$A$ & 2052 & 1123 & 62.9 & 41.9 & 49.4 & 440 \\
\hline$B$ & -180.8 & 1373 & 1007 & -48.8 & 36.6 & \\
\hline$c$ & 324.1 & 87.6 & 659 & 22.5 & 217 & 24.8 \\
\hline$D$ & 432 & 268 & 267 & 38.9 & 0.1 & \\
\hline$E$ & 6008 & 228.9 & & & & \\
\hline$F$ & 241.9 & 1662 & 125.9 & 44.9 & 39.3 & 238 \\
\hline$a$ & 166.9 & 1074 & 84.3 & 42.8 & 23.1 & 21.5 \\
\hline $\mathrm{H}$ & 474.4 & 3388 & 1327 & 55.8 & 206.1 & 8 \\
\hline 1 & 447.2 & 2897 & 1856 & 45.8 & 104.1 & 9 \\
\hline d & & 3742 & 3742 & & & \\
\hline
\end{tabular}

(注)

・AからHまでは個別循環方式の建物であり、I,Jは地区循環地区内の建物の合計值で ある(Iは2棟、Jは4 楝)。

•表内で数值の入っていない箅所はデータの無いものである。

表 5 検癿エリア（東京㧽周辺地域）における再生水需要畺

\begin{tabular}{|c|c|c|}
\hline $\begin{array}{l}\text { 東京駅周辺地区(検刢エリ } \\
\text { ア)·計画面積 } 1430000\left(\mathrm{~m}^{2}\right)\end{array}$ & $\begin{array}{c}\text { 計画供給量 } \\
\text { (m3/day) }\end{array}$ & $\begin{array}{c}\text { 雑用水需要密度 } \\
\left(\mathrm{m} 3 / \mathrm{m}^{2} \cdot \text { day }\right)\end{array}$ \\
\hline $\begin{array}{l}\text { 既存雑用水道設置施設にお } \\
\text { ける雑用水需要量 }\end{array}$ & 7,450 & 0.0052 \\
\hline $\begin{array}{l}\text { 今後の再開発による再生水 } \\
\text { 需要量 }\end{array}$ & 3,594 & 0.0025 \\
\hline 再生水需要量 合計 & 11,044 & 0.0077 \\
\hline
\end{tabular}

\section{表 6 東京都における広域循環方式の導入地区の比較}

\begin{tabular}{|c|c|c|c|}
\hline & 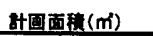 & 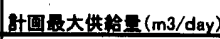 & 維用水解要蜜度 (m $3 / \mathrm{m} \cdot$-day $)$ \\
\hline 新宿·中雺坂上 & 800,000 & 8,000 & 0.0100 \\
\hline 酶海跳心 & $6,180,000$ & 30,000 & 0.0049 \\
\hline 品竖 & 830,000 & 6,000 & 0.0072 \\
\hline 大显 & 670,000 & 7,000 & 0.0104 \\
\hline 洺盟 & 310,000 & 4,000 & 0.0129 \\
\hline 八湖·東品川 & 570.000 & 4.000 & 0.0070 \\
\hline
\end{tabular}

需要量（計画可能水量）は $11,044\left(\mathrm{~m}^{3} / \mathrm{day}\right)$ となる。

（3）検討エリアへは最寄りの処理場である芝浦処理場から再生水を 供給することを想定した場合、表 1 に示すように芝浦処理場では約 66 万 $\left(\mathrm{m}^{3} / \mathrm{day}\right)$ の放流量（高級処理水）があり、検討エリアへ十分供 給可能な処理水量が確保できる。

（4）検討エリアにおける再生水の供給が、事業を行う供給者側か らみて現赛的なものであるかどうかを評価するため、東京都における 他の広域循環方式導入地域と、雑用水需要密度と単位配管あたりの 再生水供給量で比較した。再生水供給管は、下水処理場から敷設せ ず、最も近い広域循環方式導入地区から供給管を延長することでの 对応も可能であり、順次広域循踾方式導入地区がネットワーク化され ていくことにより再生水の供給がより容易となる。検討エリアへ再生水 供給管を敷設する場合、芝浦処理場から敷設する場合約 $6 \mathrm{~km}$ 、隣接 する広域循環方式導入地区（汐留地区）加敷設する場合約 $3 \mathrm{~km}$ 程 度となる。

検討エリアの雑用水需要密度に関しては、表 6 に示すように、東京 都における他の広域循環方式導入地区と同等規模の雑用水需要密度 である。また表 7 に示すように、単位配管あたりの再生水供給量は他 の供給地域と比較して多いことが分かる。

（5）次に、将来見込まれる雑用水需要の增加分を計算した。検討 エリアでは現在雑用水量の $97 \%$ がトイレ洗浄水として使われている。 3.3 での検討の通り、将来的に散水や空調用水源に再生水を使用す ることが可能になると考え、既存の雑用水利用施設と今後の再開発地 域で、最大で水消費量の $58 \%$ まで雑用水需要が增加することを想定 すると表 8 に示すように雑用水量は $21,138\left(\mathrm{~m}^{3} / \mathrm{day}\right)$ となる。

（6）更に、将来的に地域の再開発や建物更新、設備更新の際、 東京都の指導対象となる建物の雑用水需要を計算すると、少なくとも 現在の延べ床面積が維持されるものとして、延べ床面積 3 万 $\mathrm{m}^{2}$ 以上

\section{表 7 単位配管あたりの再生水供給量}

\begin{tabular}{|c|c|c|c|c|}
\hline 边理场 & 供給エリア & 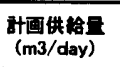 & 配整篗娫長(km) & 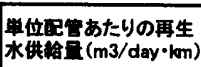 \\
\hline 落合知理地 & 斬宿·中雺坂上 & 8.000 & 11.8 & 678.0 \\
\hline 芝清边理坦 & 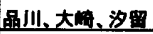 & 17,000 & 18.6 & 914.0 \\
\hline 直明处理场 & 監海副都心 & 30,000 & 26.1 & 1149.4 \\
\hline \multirow{2}{*}{ 芝消处理堨 } & \multirow{2}{*}{ 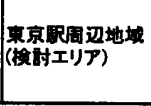 } & \multirow{2}{*}{11.044} & 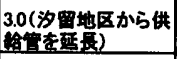 & 3681.3 \\
\hline & & & 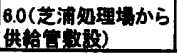 & 1840.7 \\
\hline
\end{tabular}

表 8 検討エリア（東京略周辺地域）における将来的な再生 水需要量

\begin{tabular}{|l|r|r|}
\hline $\begin{array}{l}\text { 東京駅周辺地区(検討エリ } \\
\boldsymbol{P}) \text { ·計画面積 } 1430000\left(\mathrm{~m}^{2}\right)\end{array}$ & $\begin{array}{c}\text { 計画需要量 } \\
(\mathrm{m} 3 / \text { day })\end{array}$ & $\begin{array}{c}\text { 雑用水需要密度 } \\
\left(\mathrm{m} 3 / \mathrm{m}^{2} \cdot \text { day }\right)\end{array}$ \\
\hline $\begin{array}{l}\text { 用途の拡大による再生水需 } \\
\text { 要量 }\end{array}$ & 21,138 & 0.0148 \\
\hline $\begin{array}{l}\text { 今後の雑用水利用施設の增 } \\
\text { 加による再生水需要量 }\end{array}$ & 14,848 & 0.0104 \\
\hline $\begin{array}{l}\text { 検討エリアにおける再生水 } \\
\text { 需要量 合計 }\end{array}$ & 35.986 & 0.0252 \\
\hline
\end{tabular}


の建物は 50 棟（総延べ床面積 320 万 $\mathrm{m}^{2}$ ）あり*8、全雓用系統に利 用した場合雓用水需要量は計 $14,848 \cdot\left(\mathrm{m}^{3} /\right.$ day $)$ となる。

\section{5. 結論}

本研究では、個別・地区循環方式の建物による雑用水需要を下 水処理水の供給対象として捉え、下水処理水の広域活用に資する資 料とするため、東京都区部における個別・地区循㭚方式で雑用水利 用を行う施設を対象とし、その集糟状況と雑用水需要量について調 查を行った。その成果と知見を以下の 5 点にまとめる。

（1）東京都区部における下水放流量と雑用水需要の比較を行っ た。個別・地区循嘼利用施設では、雑用水需要量で比較すると值 の大きなものから千代田区、港区、品川区、新宿区、中央区の順 であり、雑用水需要密度で比較すると千代田区、港区、中央区、渋 谷区、文京区の順となっている。

下水放流量約 440 万 $\left(\mathrm{m}^{3} / \mathrm{day}\right)$ に対して、個別循環、地区循環 方式における雑用水需要量（利用計画水量）はその $0.92 \%$ にた る約 4 万 $\left(\mathrm{m}^{3} / \mathrm{day}\right)$ となっている。

（2）個別 - 地区循環方式で雑用水利用を行う建物に再生水の供 給が可能になった場合の有効性に関して整理した。

（3）循環利用水造成プラントを設置している建物の分布図を作成 し、その集積状況を把握した。

（4）雑用水利用施設の集櫝が見られる東京駅周辺地域を対象とし て取り上げ詳細な検討を行った。その結果、検討エリアは雑用水量 (計画可能水量) $11,044\left(\mathrm{~m}^{3} / \mathrm{day}\right)$ の需要規模となる。東京の他の 広域循謤方式導入地域と、同等規模の雑用水需要密度であり、単位 配管あたりの再生水供給量は他の供給地域と比較して多くなることが分 かった。

また再生水の供給元を芝浦処理場とする場合、約 66 万 $\left(\mathrm{m}^{3} /\right.$ day $)$ の放流量（高級処理水）があり、検討エリアへ十分供給可能な処理 水量が確保できる。

（5）検討エリア内で今後全雑用系統へ再生水利用を行う場合、全 体で $21,138\left(\mathrm{~m}^{3} / \mathrm{day}\right)$ の雑用水需要が見込まれる。さらに、将来 的に地域の再開発や建物更新、設備更新の際、東京都の指導对象 となる延べ床面積 3 万 $\mathrm{m}^{2}$ 以上の建物の雑用水需要を計算すると、少 なくとも現在の延べ床面積が維持されるものとして、全雑用系統に利 用した場合計 $14,848\left(\mathrm{~m}^{3} / \mathrm{day}\right)$ 雑用水需要が見込まれる。

以上より、既設の二系統配管を有する、東京都区部における個 別・地区循睘方式で雑用水利用を行う施設は、下水処理水の供給 対象として検討の価値があることが分かった。

\section{6. 今後の展望}

本報においては東京駅周辺地域を取り上げて検討を行ったが、港 区周辺地域においても雑用水利用施設の集積が見られることから、 今後詳細な検郡を行う予定である。特に本研究において雑用水利用 施設の分布調查を行った地域は、都市再生㗨急整備地域に指定さ れている地域と重なる部分が多く、今後多くの再開発等が見込まれて いる地域であり、研究の意義は大きいと考える。

\section{謝辞}

本研究において御指導頂きました早稲田大学尾島俊雄教授、高 橋信之教授、御協力頂きました関保者の皆様に深く感謝致します。な お、本研究の一部は科学研究費 (A) 一般（課題番号：14205090、 研究課題名 : 東京 23 区における大梁度地下インフラ・トンネルのルー 卜設定に関する実証的調查研究、研究代表者：尾島俊雄）の助成を 受けて実施した。ここに記し、感謝の意を表します。

注

*1) 本報においては、人の飲用その他これに類する用途以外で低水質でもよ い用途（雉用系用途）に供される水を雓用水と呼ぶ5）８）。雓用水の水源 としては排水、雨水を利用するものとし、雓用水のうち個別・地区循環

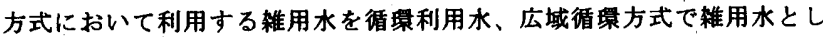
て利用する下水処理場からの再生処理水を再生水と定義する。

*2) 高度処理とは、通常の高級処理による処理水の水質をさらに向上させる ために行う処理である。通常の高䄲処理の除去物質である BOD、SS 等の 除去効率の向上のほか、高級処理では充分除去できない物質（空素、リ ン等) の除去効率の向上を目的とする ${ }^{20) 。 ~}$

*3) 雓用水道に関しては、雓用水利用施設の実熊を調查した報告2））や、紀 谷 ${ }^{5)}{ }^{111}$ 、和田 ${ }^{13)}$ 、井上 - 中島 ${ }^{14}$ ) 5 の文献、杉本・松尾 ${ }^{17}$ 、須賀・佐土 原 ${ }^{18)}$ 、和田・村上 ${ }^{18)}$ らの研究垠告がある。

*4）雑用水利用の方式に関して文献 22 の分類方法を照した。本論文では

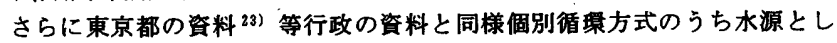
て雨水のみを処理して利用している施設に関しては雨水単独型・非循㻴 として分けて分類している。また広域循䈠方式に関して工業用水道の供 給が可能な区域においては工業用水道利用方式として分類している。

*5) 改正されたビル管理法（建筑物における衛生的基境の磪保に関する法 律）に基づく施行規則（平成 15 年 4 月 1 日施行）では、

・冷却塔及び加湿装固に供給する水は、雨水や下水処理水ではなく水道水 質基準を満たす水を用いること

・雓用水を散水、修景、清掃に使用する場合は、し尿を含む水を原水とし て用いないこと

とされている21)

*6) 主として文献 8 とヒアリンク調查により作成

*7)主として文献 9 とヒアリング麗查による

*8) 東京都都市計画局 東京都都市計画地理情報システムを用いた。

*9）各建物の年報等の凘料を閲覧し、日量平均に換算して表示

*10）文献 10 より、事務所ビルにおける延べ床面積あたりの給水量を8(1/ $\mathrm{m} 2 \cdot$ day ) とした。また再開発計画の中で具体的に雑用水利用計画量が定 められているものに関してはその值を使用した。

参考文献

1) 東京都下水道局 : 東京都下水道事業概要，pp. 18，平成 11 年度

2) 国土交通省水资源部: 雑用水利用施設実热調査, pp. 15, 平成 12 年度

3 ) 東京都下水道局 : 東京都下水道事業年報, pp. $170, p p .375$, 平成 12 年 度

4) 都市基盤整俏公団 : 望ましい水境境の形成に資する基盤整偏に関する調 查報告書, pp. 37 , 平成 12 年 3 月

5 ) 紀谷文楖他：都市をめぐる水の話, pp. 64, 井上書院, 1992

6 ) 東京都: 隺用水利用に係る指導指針

7 ) 国土交通省水資源部ホームページ ht t p : / / w w w m lit g g o jp/ tochimizushigen/mizsei/zat suyousui/kadai. html

8 ) 工業新報社：中水道システム建設奏績・計画リス卜 2003

9 ) 大手町・丸の内・有楽町地区再開発推進協議会：钤立からの概要，平 成 14 年 9 月

10) 空気調和・衛生工学会: 給排水衛生設俏計画設計の夷務の知識, pp. 33 才ーム社, 平成 11 年

11) 紀谷文㯕他：給排水衛生設偏学, TOTO出版, 1989

12）空気調和・衛生工学会: 雨水利用システム設計と実務, pp. 38 , 丸善, 1997

13）和田安彦他：水を活かす循埧境都市ぶくり，pp. 114, 技報堂出版, 2002

14）井上宇市、中島康孝：建策設借ポケットブック，相模書房，2001

15) 空気調和・衛生工学 第 53 巻 第 2 号, pp. 1-53 
16)高檑裕：都市と水 pp. 109 岩波新書 1999

17) 杉本留三、荒巻俊也、松尾友矩 : 雓用水利用の現状分析と課題に関する 考察一耯用水利用施設に対するアンケート調查を基にして，土木学会 踰文集，No. 594/VII-7，pp. 85-93， 1998.

18）須賀千衣、吉田聡、佐土原聡：東京都区部における再生水・雨水利用の 夷熊調查及びその払大の可能性に関する研究，日本建勧学会大会学術 講演梗概集，D-1 分冊, pp. 665-666，2001 年

19)和田隼人、村上公哉：西新宿地区における下水処理水を活用した排水再 利用システムに関する調查研究，日本建策学会大会学術講演梗概集， D-1 分冊, pp. 663-664，2001 年

20) 東京都下水道局 : 東京都下水道事業概要, pp. 80 , 平成 14 年度

21）㫗生労働省ホームページ：建策物における衛生的㻴境の確保に関する法 律（略称：建筑物衛生法）関連政省令の一部改正について

http://www. mhlw. go. jp/topics/2002/12/tpl218-2.html

22) 高橋裕、武内和彦編 : 地球システムを支える 21 世紀型科学技術，pp. 109 岩波講座地球裳境学 2001

23) 水の有効利用施設迸入の手引き(東京都平成 15 年 8 月)

（2003年 7 月 10 日原稿受理， 2004 年 4 月19日採用决定） 